\title{
STUDY ON ASSOCIATION OF HEPATOCELLULAR CARCINOMA WITH HEPATITIS B VIRUS INFECTION: BANGLADESH PERSPECTIVE
}

\author{
Babul Osman Chowdhury ${ }^{1}$ M Shahab Uddin Ahamad ${ }^{2}$ A H M Omer Farooque ${ }^{3}$ A J E N Rahman ${ }^{4}$
}

\begin{abstract}
Hepatocellular carcinoma ( $\mathrm{HCC}$ ) is a common visceral malignant tumour and Hepatitis $B$ virus is considered as an important etiologic agent. $\mathrm{HBV}$ is a DNA containing virus. Blood and body fluids are its primary vehicle of transmission. It causes chronic hepatic injury and malignant transformation of hepatocytes by its HBX protein. In our study we have diagnosed 43 cases of $\mathrm{HCC}$ out of 79 cases of hepatic mass lesions. The mean age of the patients is 48.55 years with a male predominance. Serum HBsAg positivity was detected in $28(61.9 \%)$ of $\mathrm{HCC}$ cases and $6(17.64 \%)$ in non-HCC cases. The association of $\mathrm{HBsAg}$ with $\mathrm{HCC}$ cases is statistically highly significant $(\mathrm{P}<.001)$ when compared with non $\mathrm{HCC}$ cases.
\end{abstract}

\section{Introduction}

The geographical distribution of hepatocellular carcinoma varies in different countries of the world. In countries where HCC is common including parts of Asia and Africa, it is frequently associated with macro nodular cirrhosis of liver and also with hepatitis $B$ virus. The close association between $\mathrm{HCC}$ and hepatitis B virus (HBV) suggests a causal relationship between the two ${ }^{1,2}$. In Africa there is also high association with aflatoxin B1.

There are two major types of primary carcinoma of liver, hepatocellular carcinoma arising from hepatocytes and cholangiocarcinoma arising from bile duct epithelium. HCC accounts for more than $90 \%$ of all primary liver cancer ${ }^{3}$. Statistically it has been found that hepatitis B carriage correlates with the frequency of HCC throughout the world. In Britain the mortality from primary liver cancer is $1-2$ per 100,000 and the carriage rate for hepatitis $B$

1. Assistant Professor of Pathology Chittagong Maa-O-Shishu Hospital Medical College, Chittagong

2. Assistant Professor of Pathology Chittagong Medical College, Chittagong

3. Associate Professor of Pathology Holy Family Red Crescent Medical College, Dhaka

4. Professor of Pathology

Bangabandhu Sheikh Mujib Medical University (BSMMU), Dhaka

Correspondence : Dr Babul Osman Chowdhury surface antigen is one per 1000 where as in China the primary liver cancer mortality is approximately 17 per 100,000 and the hepatitis B antigen carrier rate is 7.5 to $14 \%{ }^{4}$. In Taiwan, the incidence of HCC among carriers of hepatitis B surface antigen (HBsAg) is much higher than among noncarrier ${ }^{5}$. Globally, approximately $3 \%$ of world population are infected with hepatitis $\mathrm{C}$ virus with $1 \%$ to $5 \%$ increased risk of $\mathrm{HCC}^{6}$. The aim of our study was to explore the correlation of HCC with $\mathrm{HBV}$ in Bangladeshi population.

\section{Materials and methods}

This study was carried out in the department of pathology, Bangabandhu Sheikh Mujib Medical University, Dhaka during the period of October, 2001 to November 2002. A total of 79 patients of different age and sex with hepatic masses were collected from BSMMU hospital and Dhaka medical college hospital with an aim to find out the usefulness of FNAC in the diagnosis of HCC and to see the association of HCC with HBV. All necessary and relevant data of the patients were recorded methodically in a data sheet. Before performing FNA from liver, result of prothrombin time, report of USG of whole abdomen and informed written consent of the patients were obtained. Blood of the patients was collected in disposable syringes. After centrifugation serum was preserved in deep refrigerator. The serum was tested for HBsAg in ELISA method.

\section{Results}

As very little epidemiological study on $\mathrm{HCC}$ has been conducted in Bangladesh ${ }^{7}$, the purpose of this study was to diagnose hepatic SOL by FNAC and to assess the prevalence of infection by hepatitis $B$ virus in cases of $\mathrm{HCC}$. The cytological diagnosis was correlated with histology, clinical history, physical findings, serum markers, Ultrasound and CT scan report. Out of 79 cases of hepatic masses 43 were $\mathrm{HCC}, 21$ metastatic lesions and the remaining cases were liver abscesses and other lesions. The age range of $\mathrm{HCC}$ cases were between 18 to 88 years. 
The mean age was 48.55 years. The number of male patients was 41 and female were 2 . The male to female ratio was $20.5: 1$. The result is shown in table I.

Table I : Age distribution of HCC cases $(n=43)$

\begin{tabular}{|c|c|c|c|}
\hline $\begin{array}{c}\text { Age in } \\
\text { years }\end{array}$ & $\begin{array}{c}\text { Number of } \\
\text { patients }\end{array}$ & Percentage & $\begin{array}{c}\text { Mean age } \\
\text { in years }\end{array}$ \\
\hline $11-20$ & 01 & 2.32 & \\
\hline $21-30$ & 04 & 9.30 & \\
\cline { 1 - 3 } $31-40$ & 12 & 27.90 & \multirow{2}{*}{48.55} \\
\cline { 1 - 3 } $41-50$ & 10 & 23.25 & \\
\hline $51-60$ & 7 & 16.27 & \\
\hline $61-70$ & 6 & 13.95 & \\
\hline $71-80$ & 0 & 0 & \\
\hline $81-90$ & 2 & 4.65 & \\
\hline
\end{tabular}

We have taken detail history of present illness and past illness and made meticulous physical examination of the patients. The patients with HCC appeared before us at the advanced stage of the disease with overt signs and symptoms. Their duration of illness varied from I month to I year. They had dull upper abdominal pain, palpable lumps, ascites and jaundice. They had the complaints of fever, loss of appetite and loss of weight. Twenty four patients with $\mathrm{HCC}$ had previous history of acute hepatitis. One patient had history of alcohol consumption for prolonged time and two female patients had history of oral contraceptive pills for long period. The presenting clinical features of HCC are shown in table II.

Table II : Symptoms \& clinical findings of HCC cases $(n=43)$

\begin{tabular}{|l|c|c|}
\hline Signs \& symptoms & Number of patients & Percentage \\
\hline Pain in abdomen & 42 & 97.67 \\
\hline Lump in abdomen & 40 & 93.02 \\
\hline Ascites & 19 & 44.18 \\
\hline Jaundice & 15 & 34.88 \\
\hline Loss of weight & 27 & 62.79 \\
\hline Loss of appetite & 34 & 79.00 \\
\hline
\end{tabular}

Along with history and physical findings, the ultrasonography report of whole abdomen was also evaluated. The image report described the HCC lesions as single large space occupying lesion, multiple discrete lesions or as diffuse hetereogenous echogenicity. The sonological diagnosis was HCC including a differential diagnosis of metastatic lesion and vice versa. The ultrasonography findings are shown in table III.

Table III : Ultrasonography findings in HCC cases $(\mathrm{n}=43)$

\begin{tabular}{|l|c|c|c|}
\hline $\begin{array}{c}\text { USG findings } \\
\text { patients }\end{array}$ & No of & Percentage & Diagnosis \\
\hline Single SOL & 11 & 25.58 & HCC \\
\hline Multiple SOL & 23 & 53.48 & Metastatic tumor \\
\hline $\begin{array}{l}\text { Diffuse } \\
\text { heterogenicity }\end{array}$ & 9 & 20.93 & HCC \\
\hline
\end{tabular}

SOL: Space occupying lesion.

Serum of all the patients with space occupying lesion was tested for HBsAg by ELISA method. HBsAg was positive in $27(61.9 \%$ ) cases of HCC and negative in $16(38.09 \%$ ) cases of patients with HCC. In other lesions HBsAg was positive in $6(17.64 \%)$ and negative in $28(82.35 \%)$ cases. The association of HBsAg with $\mathrm{HCC}$ is statistically highly significant $(\mathrm{p}<0.001)$ when compared with non HCC cases. The result is shown in table IV.

Table IV : Association of HCC with HBsAg

\begin{tabular}{|l|c|c|c|}
\hline $\begin{array}{l}\text { Nature of } \\
\text { the lesion }\end{array}$ & \multicolumn{2}{|c|}{$\begin{array}{c}\text { HBsAg Association } \\
(\mathrm{n}=43)\end{array}$} & Significance \\
\hline & Positive & Negative & \\
\hline HCC & $27(61.90 \%)$ & $16(38.09 \%)$ & $\begin{array}{c}\text { Highly } \\
\text { Significant }\end{array}$ \\
\cline { 1 - 2 } $\begin{array}{l}\text { Others lesions } \\
\mathrm{n}=34\end{array}$ & $6(17.65 \%)$ & $28(52.35 \%)$ & \\
\hline
\end{tabular}

\section{Discussion}

On a global basis HCC is the most common visceral malignant tumour with dismal prognosis. Chronic hepatitis $B$ virus and $C$ virus infections are thought to be important etiological factors, for its development. B virus is a DNA containing virus with special affinity for liver cells. It causes chronic hepatic injury and cellular transformation. As a South East Asian country Bangladesh is considered endemic for HBV infection.

But a very few studies have been conducted here to judge the association of HBV with HCC.

In our study the average age of the HCC patients is 48.55 years. This result is almost akin to the average age of 49.15 years as reported by Das et al $(2000)^{7}$ and as that of cited by Sherlock $1993{ }^{4}$.

In this study, the mean age of $\mathrm{HBsAg}$ positive $\mathrm{HCC}$ cases is 41.92 years and that of $\mathrm{HBsAg}$ negative cases is 59.87 years. Therefore it appeared that 
hepatocellular carcinoma developed in HBV associated patients on an average of 18 years earlier than those of HBsAg negative cases The present study revealed that $61.9 \%$ of $\mathrm{HCC}$ cases are associated with HBV infection.

To detect the hepatitis $\mathrm{B}$ virus association we have investigated for HBsAg only. If other parameters were included, such as, serum anti $\mathrm{HBc}, \mathrm{HBeAg}$, HBV DNA, the result could be higher.The result of association of $\mathrm{HBV}$ with $\mathrm{HCC}$ observed in the present study is close to the results that were found in India ${ }^{8}$ and Pakistan'. In India, the prevalence of hepatitis $\mathrm{B}$ virus infection in $\mathrm{HCC}$ cases ranges from $60 \%$ to $71 \%$ and in Pakistan, the prevalence is $67 \%$ and in Philippines it is $70 \%^{11}$.

\section{Summary and conclusion}

The present study was carried out with the aim of making diagnosis of hepatocellular carcinoma from hepatic space occupying lesions and to estimate the prevalence of hepatitis $\mathrm{B}$ virus infection in $\mathrm{HCC}$ cases of Bangladeshi populations. Seventy nine cases with hepatic space occupying lesions were included in the study. The predominant type of lesion was hepatocellular carcinoma $(n=43,57.33 \%)$. HBsAg was positive in 27 cases $(61.90 \%)$. In this respect, our findings are nearer to that of our neighboring countries like India and Pakistan. In India, the association of $\mathrm{HBV}$ is 60 to $71 \%^{12}$ and in Pakistan it is $67 \%{ }^{13}$. Therefore it is apparent from the study that in Bangladeshi populations $\mathrm{HCC}$ has a highly significant association $(\mathrm{p}<.001)$ with $\mathrm{HBV}$ infection. Moreover, HBsAg positive cases are more likely to develop poorly differentiated hepatocellular carcinoma, liable to follow an aggressive course.

\section{References}

1. Akagi Go, Fureya K, Otsuka H. Hepatitis B antigen in the liver in hepatocellular carcinoma in Shikokua, Japan. Cancer 1982; 49: 678-682

2. Beasely RP. Hepatitis B virus as the etiologic agent in hepatocellular carcinoma-Epidemiologic consideration. Hepatology 1982: 215

3. Cotran RS, Kumar V, Kollins T, Rabbins Pathologic Basis of Disease, 6th edition, Philadelphia, W B Saunders Company, 1999: 846-891

4. Sherlock S, Dooley j. Diseases of the liver and biliary system, 9th edition, Oxford. Blackwell Scientific Publication, 1993: 503-529
5. Beasely RP, Hwang LY, Chin LC, Siang CC.Hepatocellular carcinoma and hepatitis B virus-A prospective study of 22707 men in Taiwan. The Lancet; November 1981: 1129-1132

6. WHO Report, 1999. Cited in Romedica, April 2002

7. Das JC, Azad AK, Mamun SAA, Rahman MR et al. Clinical presentation and out come of hepatocellular carcinoma. Journal of Bangladesh College of Physicians and Surgeons 2000; 18: 55-60

8. Vogel EL, Anthony PP, Mody N, Barker LF. Hepatitis associated antigen in Ugandan patients with hepatocellular carcinoma, The Lancet 1970; 621-624

9. Obata H, Hayashi N, Motoike Y. A prospective study on the development of hepatocellular carcinoma from liver cirrhosis with persistent hepatitis B virus infection. Cancer 1980; 25: 741-747

10. Sarin SK, Thakur V, Gupta RC et al. Profile of hepatocellular carcinoma in India, an insight into the possible etiologic associations. J Gastroenterol Hepatol 2001; 6: 66-73

11. Lingao AL, Domingo EO, Nishoka K. Hepatitis $B$ virus profile of hepatocellular carcinoma in the Philippines. Cancer 1981; 48: 1590-1593

12. Tandon BN, Acharya SK, Tandon A. Epidemiology of hepatitis B virus infection in India, Gut 1996; 38: 56-59

13. Mujeeb A, Jamal Q, Khamani R, Iqbal N, Kaher $S$, Prevalence of hepatitis Bsurface antigen and $\mathrm{HCV}$ antibodies in hepatocellular carcinoma cases in Karachi, Pakistan. Trop Doct 1997: 45-46 